\title{
Pengaruh Multi Level Marketing Terhadap Penjualan Produk Serum Vitamin C Salisa
}

\author{
Wiranto Joshua Christofel Effendi \\ J.A.F. Kalangi \\ Danny D.S. Mukuan \\ Jurusan Ilmu Administrasi, Program Studi Administrasi Bisnis \\ Fakultas Ilmu Sosial dan Politik, Universitas Sam Ratulangi Manado \\ Email : josuaeffendi26@gmail.com
}

\begin{abstract}
The purpose of this study was to examine the effect of Multi level Marketing on the sale of Serim Vitamin C Salisa. Cosmetics has become one of human needs in general. One of the cosmetics companies that saw this opportunity and marketed their products in Indonesia, namely PT. Aura Cantik Indonesia. This type of research is quantitative research. The data validity test results obtained all items in question declared valid. Furthermore Anova output above is known that the calculated $F$ value $=744,645$ with a significance of 0,000 $<0.05$ then the regression model can be used to predict Multi Level Marketing $(X)$ variables or in other words there is the influence of Multi Level Marketing $(X)$ variables on Sales variables ( $Y)$. Furthermore, the results of the Determination Coefficient Test, $R$ Square of $88.5 \%$ which states that the variable Sales of Vitamin C Salisa (Y) Serum Products is influenced by the Multi Level Marketing (X) influence variable, while the remaining $11.5 \%$ is influenced by other variables that are not in this study.
\end{abstract}

Key words: Multi Level Marketing, Sales

\section{Pendahuluan}

Kecantikan adalah keelokan wajah yang dimiliki pada wanita. Kecantikan yang dimiliki seorang wanita, menjadikan wanita tampak percaya diri dalam eksistensi dirinya. Banyak cara yang digunakan oleh wanita dalam mempercantik diri yaitu salah satunya dengan menggunakan kosmetik. Beragam kosmetik yang ada di pasaran untuk memenuhi kebutuhan wanita dalam mempercantik diri, menjadikan wanita memiliki banyak pilihan produk kecantikan.

Pembelian suatu produk kosmetik bukan lagi untuk memenuhi keinginan (wants) saja, melainkan karena kosmetik adalah sebuah kebutuhan (needs) pada saat ini. Kosmetik saat ini telah menjadi kebutuhan manusia yang tidak bisa dianggap sebelah mata lagi. Sekarang semakin terasa bahwa kebutuhan adanya kosmetik yang beraneka bentuk dengan ragam warna dan keunikan kemasan serta keunggulan dalam memberikan fungsi bagi 
konsumen, menuntut industri kosmetik untuk semakin terpicu mengembangkan teknologi yang tidak saja mencakup peruntukkannya dari kosmetik itu sendiri namun juga kepraktisan di dalam penggunaannya (Media Indonesia, Rabu 4 Juni 2008: 19).

Industri kosmetik menjadi salah satu industri yang memiliki perkembangan pesat dari tahun ke tahun. Bahkan industri ini mengantongi predikat sebagai penyumbang nilai ekspor tinggi bagi negara. Meski terkesan kurang terekspos media, tapi nyatanya industri kosmetik terus memberikan perkembangan yang signifikan dibanding industri lainnya. Industri kosmetik menjadi lahan industri strategis dan potensial sebagai ladang investasi.

Saat ini terdapat 760 perusahaan kosmetik yang tersebar di Indonesia (www.kemenperin.go.id, 2018). Selain itu industri kosmetik menyerap 75.000 tenaga kerja langsung dan 600.000 tenaga kerja tidak langsung. Industri kosmetik nyatanya mampu memperluas nilai ekspor hingga Rp 11 triliun paada tahun 2015. Diharapkan tahun ini akan semakin meningkat. Selain itu, nilai impor baik bahan baku maupun mesin mencapai USD 516,99 juta. Hal ini menjadikan perdagangan produk kosmetik tanah air mengalami surplus sekitar 95\% (kemenperin.go.id, 2018).
Persaingan antar pasar industri perawatan pribadi dan kosmetik semakin kompetitif. Hal ini terbukti dengan banyaknya jenis kosmetik produksi dalam negeri dan produksi luar negeri yang beredar baik di Indonesia. Membanjirnya produk kosmetik di pasaran mempengaruhi minat seseorang terhadap pembelian dan berdampak pada penjualan. Salah satu perusahaan kosmetik yang melihat peluang tersebut dan memasarkan produknya di Indonesia yaitu PT. Aura Cantik Indonesia.

Sebelum adanya PT. Aura Cantik Indonesia, awalnya bernama Pabrik Alpha Omega Abadi yang berdiri pada tahun 1999 sudah dan sampai saat ini sudah berusia 20 tahun, dan menciptakan anak perusahaan yaitu PT. Aura Cantik Indonesia. PT. Aura Cantik Indonesia didirikan pada tahun 2017 dan sudah berusia 2 tahun sampai sekarang.

Salisa Serum Vitamin C merupakan produk andalan dari PT. Aura Cantik Indonesia. Salisa Serum Vitamin C adalah produk lokal yang aman digunakan untuk semua jenis kulit. Salisa Serum Vitamin C memiliki manfaat anti aging, mencerahkan, meregenerasi sel-sel kulit mati, melembabkan kulit, menghilangkan jerawat serta memudarkan bekas jerawat dan mengecilkan pori-pori besar. Harga produk Salisa Serum Vitamin C Rp. 150.000 yang jual dengan menggunakan sistem Multi Level Marketing. 
Multi Level Marketing (MLM) adalah salah satu sistem pemasaran dengan memanfaatkan pelanggan sebagai jaringan distribusi. Istilah lain Multi Level Marketing adalah Network Marketing, Multi Generation Marketing dan Uni Level Marketing. Berdasarkan akar katanya, Multi artinya banyak, level artinya berjenjang dan Marketing artinya pemasaran, sehingga Multi Level Marketing adalah pemasaran yang banyak dan berjenjang.. Produk dan jasa yang ada semakin beraneka ragam, dan dalam tahun ke tahun semakin banyak perusahaan yang berdiri dengan produk andalan mereka. Semakin banyak kompetitor semakin besar juga persaingan yang akan terjadi, jika sudah begini dibutuhkan strategi dan konsep Multi Level Marketing yang mampu menarik minat konsumen. Dalam dunia Multi Level Marketing seperti saat ini banyak dibutuhkan Multi Level Marketing yang memiliki kualitas dan bekerja secara profesional sehingga Multi Level Marketing yang mereka kenalkan ke khalayak akan tepat sesuai target dari produk melalui brief yang sudah disepakati tersebut.

Eksistensi suatu Multi Level Marketing tidak luput dari klien, klien merupakan hal yang penting dalam suatu Multi Level Marketing. Pemasukan pendapatan dan keloyalan dari klien adalah sasaran utama untuk terus maju dan bertahan dalam persaingan dunia usaha dan bisnis seperti saat ini. Strategi komunikasi yang diterapkan merupakan salah satu hal terpenting dalam mempertahankan klien dari persaingan bisnis yang dilakukan oleh kompetitor lain demi mendapatkan kepercayaan klien/konsumen. Persaingan antar Multi Level Marketing akan selalu ada dan meningkat dari tahun ke tahun, peningkatan tersebut untuk mempertahankan eksistensi dari

\section{Multi Level Marketing}

Menurut Muslich (2015), Multi Level Marketing adalah sebuah sistem pemasaran modern melalui jaringan distribusi yang dibangun secara permanen dengan memposisikan pelanggan perusahaan sekaligus sebagai tenaga pemasaran. Dengan kata lain, dapat dikemukakan bahwa Multi Level Marketing adalah pemasaran berjenjang melalui jaringan distribusi yang dibangun dengan menjanjikan konsumen (pelanggan) sekaligus sebagai tenaga pemasaran.

Menurut Harefa (2000), Multi Level Marketing adalah menjual atau memasarkan langsung suatu produk baik berupa barang atau jasa konsumen, sehingga biaya distribusi dari barang yang dijual atau dipasarkan tersebut sangat minim bahkan sampai ke titik nol yang artinya bahwa dalam bisnis MLM ini tidak 
diperlukan biaya distribusi. Multi Level Marketing (MLM) juga menghilangkan biaya promosi dari barang yang hendak dijual karena distribusi dan promosi ditangani langsung oleh distributor dengan sistem berjenjang.

\section{Sejarah Multi Level Marketing}

Sejarah mencatat suatu pemasaran dengan sistem jaringan ini bermula sekitar tahun 1930-an M., ketika perusahaan Nutrilite Produced Inc. yaitu sebuah perusahaan yang berkedudukan di California, Amerika Serikat meluncurkan produk makanan suplemen. Perusahaan ini menerapkan sistem bonus sebesar 2\% kepada setiap penjual yang dapat merekrut penjual baru. Perusahaan yang didirikan oleh Carl F. Rehnborg pada tahun 1934 M. ini, memberikan komisi tambahan kepada distributor barunya yang berhasil merekrut, melatih, mengajarkan dan membantu distributor baru dalam menjual Nutrilite kepada konsumen (Rozi, 2005 : 108-109).

Dalam perkembangannya, terdapat beberapa orang yang menyempurnakan pemasaran jaringan ini, mereka adalah Dr. Forrest Shaklee, Richad De Vos dan Jay Van Andel. Pada tahun 1950-an M., ketika Nutrilite mengalami guncangan internal manajemen perusahaan. Dr. Forrest Shaklee keluar dari distributornya dan pada tahun 1956 M. mendirikan Shaklee
Corporation, yaitu perusahaan yang memfokuskan pada produksi makanan tambahan (suplemen food). Dr. Forrest Shaklee berhasil mengembangkan perusahaannya menjadi perusahaan multinasional dan menyebar di beberapa negara seperti Inggris, Kanada, Malaysia, Filipina, Jepang dan Singapura (Rozi, 2005 : 108-109)

Selain itu, akar Multi Level Marketing tidak lepas dari berdirinya Amway Corporation pada tahun 1959 M. di Michigan, Amerika Serikat. Pendiri Amway Corporation dan pelopor berdirinya perusahaan ini adalah Richad De Vos dan Jay Van Andel yang pernah menjadi distributor Nutrilite. Perusahaan Amway kemudian semakin dikenal ketika mereka menggunakan sistem pendukung Network Twenty One yang dirancang oleh Jim dan Nacy Dornan. Perusahaan ini memperkenalkan penjualan produk-produk rumah tangga (Kuswara, $2005: 18$ ).

Seiring dengan berjalannya waktu, perusahaan ini semakin berkembang pesat dengan memasarkan berbagai jenis dan macam produk sehingga Amway dikenal sebagai pelopor produk Multi Level Marketing pertama yang memasarkan berbagai macam produk. Amway sebagai perusahaan yang memasarkan produknya dengan sistem jaringan, hingga saat ini masih merupakan perusahaan besar dan 
yang telah beroperasi beberapa puluh tahun lamanya di berbagai negara termasuk masuk ke Indonesia pada tahun 1998 M. (Rozi, 2005 : 110-111).

Inti dari bisnis Multi Level Marketing digerakkan dengan jaringan, baik bersifat vertikal atas bawah maupun horizontal kiri kanan atau pun gabungan antara keduanya (Benny, Sistem pemasaran ini memiliki perbedaan dengan sistem pemasaran lainnya. Ciri-ciri khusus yang dimiliki oleh Multi Level Marketing adalah terdapat jenjang, melakukan perekrutan anggota baru, penjualan produk, serta adanya bonus atau komisi di setiap jenjangnya tersebut. Dalam sistem ini, calon distributor seperti layaknya 'membeli' hak atau tanda milik khusus untuk merekrut anggota baru, menjual produk dan mendapatkan kompensasi dari hasil penjualannya sendiri maupun hasil penjualan anggota yang direkrut di dalam organisasi jaringannya. Selain Multi Level Marketing, terdapat sistem lain yang termasuk kategori ini, yaitu sistem single level marketing dan sistem limited level marketing tetapi ketiga-tiganya ini berbeda karakteristik yang dimilikinya (Kuswara, 2005 : 36-38).

Dalam istilah marketing sebenarnya tidak hanya mencakup penjualan saja, namun lebih luas aspek yang terkandung dalam marketing di antaranya suatu atau beberapa produk, harga, promosi, distribusi dan sebagainya. Sehingga tidak hanya dapat dimaknai secara tunggal dan menjual itu sendiri merupakan bagian dari kegiatan transaksi penukaran produk dengan uang. 2002: 28).

\section{Penjualan}

Menurut Moekijat "Dalam Buku Kamus Istilah Ekonomi” (2000) yang menyatakan bahwa "selling" melakukan penjualan ialah suatu kegiatan yang ditujukan untuk mencari pembeli, mempengaruhi dan memberikan petunjuk agar pembeli dapat menyesuaikan kebutuhannnya dengan produk yang ditawarkan serta mengadakan perjanjian mengenai harga yang menguntungkan bagi kedua belah pihak.

Menurut Philip Kotler (2000) yang diterjemahkan oleh Ronny A. Rusli dan Hendra dalam buku "Manajemen Pemasaran" pengertian penjualan ialah "penjualan ialah proses sosial manaherial dimana individu dan kelompok mendapatkan apa yang mereka butuhkan dan inginkan, menciptakan, menawarkan dan mempertukarkan produk yang bernilai dengan pihak lain.

Menurut Assuari (2004) berpendapat bahwa "penjualan ialah sebagai kegiatan manusia yang mengarahkan untuk memenuhi dan memuaskan kebutuhan dan keinginan melalui proses pertukaran”. 
Menurut Haryono (2003) bahwa penjualan kredit ialah penjualan yang dilakukan bilamana pembayaran baru diterima beberapa waktu kemudian.

Menurut Kusnadi "Dalam Buku Akuntansi Keuangan” (2000) menjelaskan bahwa penjualan "sales" ialah sejumlah uang yang dibebankan kepada pembeli atas barang atau jasa yang dijual.

Menurut Basu Swastha "Dalam Bukunya Berjudul Azas-Azas Marketing” (2001) penjualan ialah ilmu dan seni mempengaruhi pribadi yang dilakukan oleh penjual, untuk mengajak orang lain bersedia membeli barang atau jasa yang ditawarkan. Jadi dalam buku Basu Swastha menerangkan bahwa penjualan yaitu proses menawarkan barang atau produk kepada konsumen dengan cara merayu konsumen tersebut.

\section{Metode Penelitian}

Jenis penelitian ini adalah penelitian kuantitatif dengan menggunakan metode pendekatan explanatory research. Menurut Sugiyono (2012: 8), metode penelitian kuantitatif dapat diartikan sebagai metode penelitian yang berlandaskan pada filsafat positivisme, digunakan untuk meneliti pada populasi atau sampel tertentu, teknik pangambilan sampel pada umumnya dilakukan secara random, pengumpulan data menggunakan instrumen penelitian, analisis data bersifat kuantitatif atau statistik dengan tujuan untuk menguji hipotesis yang telah ditetapkan.

Sedangkan jenis penelitian eksplanatori (explanatory research) bertujuan untuk menguji teori. Menurut Ferdinand (2006: 5), metode explanatory research membangun teori yang dikembangkan, penelitian dapat dibedakan menjadi penelitian yang bertujuan membangun proporsi dan hipotesis serta penelitian yang bertujuan menguji hipotesis.

Berdasarkan jenis penelitian tingkat penjelasan, maka tipe penelitian ini adalah penelitian asosiatif. Penelitian asosiatif adalah penelitian yang bertujuan untuk mengetahui hubungan antara dua variabel atau lebih. Pada akhirnya hasil penelitian ini menjelaskan hubungan kausal antar variabel-variabel melalui pengujian hipotesis.

Pada penelitian ini penulis berusaha menjelaskan hubungan antar variabel Multi Level Marketing (X), dan penjualan (Y).

\section{Hasil Penelitian}

Penelitian ini dilaksanakan pada tanggal 20 juli sampai 19 agustus 2019. Dalam penelitian ini sampel yang digunakan berjumlah 99 responden. Pernyataan yang diajukan kepada responden sebanyak 10 pernyataan dimana 5 item pernyataan tentang Multi Level 
Marketing dan 5 item pernyataan tentang penjualan produk. Keseluruhan kuesioner ini diolah dengan bantuan menggunakan SPSS for windows versi 25.00 .

Berdasarkan hasil penelitian yang dilakukan, maka hasil rekapitulasi data dapat dipaparkan sebagai berikut:

Berdasarkan data yang diperoleh dari penyebaran kuisioner terlihat bahwa pada tabel diatas jumlah responden yang berjenis kelamin laki-laki berjumlah 29 orang dengan persentase $30 \%$, sedangkan untuk responden perempuan berjumlah 70 orang dengan persentase $70 \%$. Dari tabel diatas dapat dilihat bahwa responden yang paling banyak yaitu berjenis kelamin perempuan.

Karakteristik Responden Berdasarkan Umur

Sumber : Hasil dari olah data, 2019

Berdasarkan data yang diperoleh dari penyebaran kuisioner terlihat bahwa pada tabel diatas pada usia 17 tahun - 20 tahun yaitu sebanyak 13 orang dengan persentase $13.14 \%$, usia 21 tahun - 22 tahun sebanyak 27 orang dengan persentase $27.27 \%$, usia 23 tahun - 25 tahun sebanyak 32 orang dengan persentase $32.32 \%$, dan usia 26 tahun- 28 tahun sebanyak 27 orang dengan persentase $27.27 \%$. Sehingga dapat disimpulkan dari 99 sampel terbanyak pada usia 23 tahun - 25 tahun. Berdasarkan data yang diperoleh dari penyebaran kuisioner terlihat bahwa pada tabel diatas, pengguna
1 kali sebanyak 5 orang dengan persentase $5.05 \%$, pada penggunaan sebanyak 2-3 kali 10 orang dengan persentase $10.10 \%$, pada penggunaan 4-6 kali sebanyak 40 orang dengan persentase $40.5 \%$, dan pada penggunaan setiap hari 44 orang dengan persentase $44.44 \%$. Dengan hasil data yang diperoleh diatas maka dapat dikatakan bahwa pengaruh Multi Level Marketing pengguna Serum Vitamin C Salisa adalah setiap hari. Uji validitas terhadap instrument dimaksudkan untuk mengetahui apakah instrument yang digunakan layak digunakan dalam penelitian ini. Sampel yang digunakan sebanyak 99 responden maka nya adalah 0, 195 Pengujian validitas instrumen dilakukan dengan menggunakan SPSS Statistic dengan kriteria berikut: Jika $r$ hitung $>r$ tabel, maka pernyataan tersebut dinyatakan valid dan jika $r$ hitung $<\mathrm{r}$ tabel, maka pernyataan tersebut dinyatakan tidak valid.

Berdasarkan tabel diatas semua item pernyataan variabel kualitas pelayanan $(\mathrm{X})$ yang diolah menggunakan SPSS for windows versi 25.00 dimana 5 item pernyataan menunjukan nilai lebih besar dari nilai sehingga dapat disimpulkan bahwa pada uji validitas variabel kualitas pelayanan $(\mathrm{X})$ dinyatakan valid atau dapat dilanjutkan sebagai data penelitian. Berdasarkan tabel diatas semua item pernyataan variabel penjualan (y) yang 
diolah menggunakan SPSS for windows versi 25.00 dimana 5 item pernyataan menunjukan nilai lebih besar dari nilai sehingga dapat disimpulkan bahwa pada uji validitas variabel Penjualan (y) dinyatakan valid atau dapat dilanjutkan sebagai data penelitian. Uji reliabilitas yaitu untuk menguji konsistensi alat ukur, apakah hasilnya akan tetap konsisten atau sesuai dengan uji sebelumnya. Pengukuran kuesioner yang reliable dengan uji reliabilitas apabila $\mathrm{r}$ alpha $>\mathrm{r}$ table 0,195 maka pernyataan reliable Jika $r$ alpha $<\mathrm{r}$ table 0,195 maka pernyataan tidak reliable. Berdasarkan hasil perhitungan uji reliabilitas variabel pengaruh Multi Level Marketing menggunakan spss for windows versi 25.00, diperoleh nilai alpha cronbrach sebesar 0,972. Dari hasil tersebut instrument penelitian variabel pengaruh Multi Level Marketing dinyatakan reliable dan dapat dilakukan sebagai alat ukur penelitian selanjutnya. Sedangkan berdasarkan hasil perhitungan uji reliabilitas variabel penjualan diperoleh nilai cronbrach alpha sebesar 0,923 sehingga instrument penelitian variabel penjualan dinyatakan reliable dan dapat dilakukan sebagai alat ukur penelitian selanjutnya. Analisis regresi linier sederhana digunakan untuk mengetahui pengaruh Multi Level Marketing terhadap penjualan Serum Vitamin C Salisa.
Berdasarkan hasil data menggunakan spss versi 25.00 for windows diperoleh sebagai berikut: Dari persamaan diatas dapat dijelaskan bahwa nilai kostanta sebesar 2,274 dimana mengandung arti bahwa nilai konsisten variabel Multi Level Marketing adalah 2,274. Kemudian koefisien regresi X sebesar 0,908 artinya pengaruh Multi Level Marketing terhadap penjualan produk Serum Vitamin C Salisa ini baik atau terjadi penambahan pada variabel pengaruh Multi Level Marketing maka penjualan produk Serum Vitamin C Salisa di Kota Manado akan meningkat sebesar 0,908, sehingga dapat dikatakan bahwa arah pengaruh Multi Level Marketing terhadap penjualan produk Serum Vitamin C Salisa adalah positif.

Uji $F$ ini digunakan untuk mengetahui apakah terdapat pengaruh yang signifikan antara variabel Multi Level Marketing (X) dan terhadap variabel Penjualan (Y). Dari ouput diatas diketahui bahwa niali $\mathrm{F}$ hitung $=744,645$ dengan signifikansi sebesar $0,000<0,05$ maka model regresi dapat dipakai untuk memprediksikan variabel Multi Level Marketing (X) atau dengan kata lain ada pengaruh variable Multi Level Marketing (X) terhadap variabel Penjualan (Y). Uji $\mathrm{t}$ digunakan untuk menguji signifikansi hubungan antara variabel $\mathrm{X}$ dan Y. dengan kriteria pengujian perbandingan $t$ hitung dengan $t$ tabel.jika: 
thitung $>\mathrm{t}$ tabel maka Ha diterima dan Ho ditolak dan thitung $<\mathrm{t}$ table maka $\mathrm{Ha}$ ditolak dan Ho diterima. Adapun dengan kriteria pengujian (berdasarkan signifikansi) jika: Jika signifikansi < 0, 05 maka Ha diterima atau jika signifikansi > 0 , 05 maka Ha ditolak Dari tabel diatas diperoleh $\mathrm{t}$ hitung untuk variabel Multi Level Marketing adalah sebesar 27,288 dengan signifikansi 0,000 . Nilai sig uji t yang lebih kecil $(<)$ dari 0,05 yang menunjukan diterima hipotesis yang menyatakan Multi Level Marketing berpengaruh terhadap Penjualan Serum Salisa Vitamin C di Kota Manado. Koefisien determinasi bertujuan untuk mengetahui seberapa kemampuan variabel $\mathrm{X}$ menjelaskan variabel $\mathrm{Y}$. berdasarkan pada pengolahan data SPSS versi 25.00 koefisien determinasi dapat dilihat dari tabel sebagai berikut. Berdasarkan hasil tabel dengan bantuan SPSS. Untuk mengetahui seberapa besar variabel bebas dapat mempengaruhi variabel terikat serta untuk mengukur besarnya kontribusi variabel $\mathrm{X}$ terhadap variasi (naik turunnya) variabel Y. Maka dapat diketahui nilai $\mathrm{R}$ Square adalah 0,885 atau 88,5\%. Artinya variabel Multi Level Marketing (X) memberikan kontribusi sebesar $88.5 \%$ terhadap Penjualan (Y). Berdasarkan tabel diatas maka koefisien korelasi $\mathrm{R}$ Square yang ditemukan sebesar adalah
0,885 atau $88,5 \%$ dimana termasuk pada kategori sangat kuat sehingga terdapat hubungan yang sedang antara Muti Level marketing terhadap Penjualan Serum Salisa Vitamin C di Kota Manado.

\section{Pembahasan}

Berdasarkan data yang diperoleh dari penyebaran kuisioner terlihat bahwa jumlah konsumen yang paling banyak memakai prodak Salisa yaitu berjenis kelamin perempuan. Berdasarkan data yang diperoleh dari penyebaran kuisioner terlihat bahwa pengaruh Multi Level Marketing, atau penggunaan Serum Vitamin C Salisa dinyatakan valid jika $\mathrm{r}$ hitung lebih dari $\mathrm{r}$ tabel. Berdasarkan dari nilai konstanta dimana mengandung arti bahwa nilai konsisten variable Multi Level Marketing berpengaruh baik terhadap penjualan produk Serum Vitamin C Salisa, dengan demikian hasil ini baik atau terjadi penambahan pada variable pengaruh Multi Level Marketing, maka penjualan produk Serum Vitamin C Salisa di kota Manado bisa berkembang, sehingga dapat di katakana bahwa pengaruh Multi Level Marketing terhadap penjualan produk Serum Vitamin C Salisa adalah positif. Penelitian ini untuk mengetahui seberapa besar varibel bebas dapat mempengaruhi variable terikat serta untuk mengukur besarnya kontribusi variable $\mathrm{X}$ terhadap 
variasi (naik turunnya) variable Y. Maka dapat di ketahui variable Multi Level Marketing (X) memberikan kontribusi yang signifikan terhadap penjualan (Y).

\section{Simpulan}

Berdasarkan hasil penelitian dapat dismpulkan bahwa kualitas pengaruh Multi Level Marketing terhadap Penjualan Produk Serum Vitamin C Salisa di Kota Manado, dapat berkembang dengan mempertimbangkan kebutuhan konsumen prodak Serum Vitamin C Salisa. Maka dari itu PT Aura Cantik Indonesia perlu memproduksikan prodak-prodak terbaru agar menambah minat/daya beli konsumen,agar supaya prodak Salisa bisa bersaing dengan prodak-prodak kosmetik lainya, bukan hanya persaingan dalam negeri tapi juga dapat bersaing dengan prodak-prodak kosmetik yang ada di luar negeri. Dengan adanya hasil penelitian ini dapat diartikan bahwa pengaru Multi Level Marketing terhadap Penjualan sangat berpengaruh terhadap produk Serum Vitamin C Salisa di PT. Aura Cantik Indonesia.

\section{Referensi}

Assuari, S. (2004). Manajemen Produksi dan Operasi, Lembaga Penerbit Fakultas Ekonomi Universitas Indonesia
Augusty, F. (2006). Metode Penelitian Manajemen. Semarang: Badan. Penerbit Universitas Diponegoro. Azwar, Syaifuddin. 2005.

Basu, S. (2001). Manajemen Penjualan, cetakan kelima. BFSE: Yogyakarta.Brawijaya.

Harefa A. (2000). Menjadi Manusia Pembelajar: Pemberdayaan diri, transformasi organisasi dan masyarakat lewat proses pembelajaran menuju Indonesia 2015.

Kotler, P. (2005). Manajemen Pemasaran. Jilid 1 dan 2. Jakarta: PT Indeks

Kuswara. (2005). Mengenal MLM Syariah. Tangerang: Amal Actual.

Moekijat. (2000). Kamus Manajemen, Bandung, Penerbit CV. Mandar Maju.

Muslich Ahmad Wardi 2015. Fiqh Muamalat 2015

Rozi, F. dan R. Krisdiana. (2005). Prospek Ubi Jalar Berdaging Ungu Sebagai Makanan Sehat dalam Mendukung Ketahanan Pangan. Laporan Penelitian. Balai Penelitian Tanaman Kacang-kacangan dan Umbi-umbian, Malang.

Sugiyono, (2012). Metode Penelitian Bisnis. Bandung : Alfabeta. 